\title{
Yellowfin Seabream, A Target Species for Monitoring of Coastal Pollutants
}

\section{Aliakbar Hedayati* \\ Faculty of Fisheries and Environment, Gorgan University of Agricultural Sciences and Natural Resources, Gorgan, Iran}

*Corresponding author: Aliakbar Hedayati, Faculty of Fisheries and Environment, Gorgan University of Agricultural Sciences and Natural Resources. Gorgan, Iran, Tel: +989131528572; E-mail: marinebiology1@gmail.com

Received date: February 23, 2016; Accepted date: February 24, 2016; Published date: March 04, 2016

Copyright: ( 2016 Hedayati A. This is an open-access article distributed under the terms of the Creative Commons Attribution License, which permits unrestricted use, distribution and reproduction in any medium, provided the original author and source are credited.

\section{Fish Species for Eco-Toxicological Studies}

For several reasons, fish species have attracted considerable interest in studies assessing biological and biochemical responses to contaminants. Despite their limitations, such as a relatively high mobility, fish are generally considered to be the most feasible organisms for pollution monitoring in aquatic systems. Fishes are by far the most diverse class of vertebrates; the 28,000 species identified to date are greater than the combined numbers for the other classes [1].

This taxonomic diversity is reflected in a diversity of body forms, lifestyles, and physiologies, which also reflect the great diversity of aquatic systems that fish inhabits, from freshwater to hypersaline waters, with temperatures ranging from below freezing to $>45^{\circ} \mathrm{C}$, pressures ranging from 1 to $1000 \mathrm{Atm}$, and other variability's in solar radiation, oxygen concentrations, ionic and organic matter compositions, turbulence, bottom environments, and so forth. This diversity has driven the use of fishes for scientific inquiries into the influences of environmental variables on the evolution and adaptations of organisms [2].

The study of mechanisms of toxicity in fish involves two distinct rationales, with fish serving both as targets and as models. Clearly, fish are targets for environmental contaminants; some fish populations are highly exposed to chemicals, especially in urban, industrial, or coastal sites (e.g. Yellowfin seabream) [3]. These fish are studied because of concern for population-level effects or as sentinels for the health of the environment. In addition, they may be subjects of research to investigate the mechanisms involved in physiological adaptation to chemical exposure [4].

Fish also are widely used as animal models in toxicological research, with the ultimate goal of extrapolating the results to inform questions concerning the potential human health effects of chemical exposure. Thus, research in fish toxicology involves a two-way extrapolation, with human results being used to establish mechanisms of relevance to fish as targets, and fish being used as models to address specific mechanistic questions with application to human health.

Several criteria should be used in selecting fish species for ecotoxicological testing [2]:

- Widely available fish species with adequate background information.

- Fish species with a known history of diverse sensitivities and behavioral strategies.

- Indigenous, representative fish species of the receiving system being studied should be considered first. If definable and possible, a keystone fish species should be used. Keystone species are those that influence a community because they play a significant role in the community, not because of their numerical dominance.

- Species must be amenable to culturing and maintenance in the laboratory.

- Test species can be collected from wild populations, cultured in the laboratory or purchased from a commercial supplier.

\section{Yellowfin Seabream, Suitable Marine Fish Species}

Yellowfin Seabream (A. latus) known as Grey Bream, Japanese Silver Bream, Yellow Sea Bream, Yellow Seabream, Yellow-Finned Black Porgy). It is belongs to Phylum: Chordata (chordates), Subphylum: Vertebrata (vertebrates) Infraphylum: Gnathostomata (jawed vertebrates), Superclass: Osteichthyes (bony fishes), Class: Actinopterygii (ray-finned fishes), Order: Perciformes (perch-like fishes), Suborder: Percoidei, Family: Sparidae, Genus: Acanthopagrus and Species: Acanthopagrus latus [5] (Figure 1) with max size $50.0 \mathrm{~cm}$ TL (male/unsexed); and max weight: $1500 \mathrm{~g}$. It lives in demersal environment of freshwater, brackish and marine water within $34^{\circ} \mathrm{N}$ $20^{\circ} \mathrm{S}, 48^{\circ} \mathrm{E}-154^{\circ} \mathrm{E}$ (including Indo-West Pacific: Persian Gulf and along the coast of India to the Philippines, north to Japan, south to Australia). It Occurs in shallow coastal waters and enters river mouths and estuaries. Often feeds in tidal flats, mainly on echinoderms, worms, crustaceans and mollusks [6].

A. latus is a protandrous hermaphroditic sparid (Porgies) [3]. Yellowfin seabream, the natural inhabitant of the creeks studied, are found in the shallow water of the intertidal zone that experiences dual fluctuations in both temperature and salinity. This fish is under threat because of their continuous exposure to toxic chemical-rich industrial effluents that are discharged into the creeks.

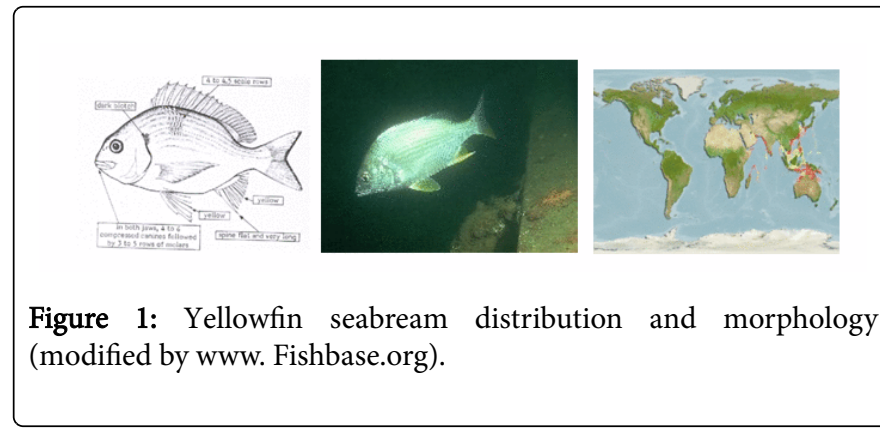

Yellowfin sea bream is considered to be one of the most commercially important marine fish in Iran, due to its consumer preference and is newly successful cultured in the coastal area of Iran, especially in Khuzestan province. These economically important fish are under threat because of their continuous exposure to toxic 
Citation: Hedayati A (2016) Yellowfin Seabream, A Target Species for Monitoring of Coastal Pollutants. J Coast Zone Manag 19: e116. doi:

Page 2 of 2

chemical-rich industrial effluents that are discharged into the Persian Gulf and their enclosed creeks. wild stocks of sea bream have declined substantially in recent years [3], owing to overexploitation, pollution and illegal fishing practices, there is an urgent need to revive them through processes of conservation, management, and mariculture, knowledge of the mainly common pollution effect on vital organ of this fish, is a basic prerequisite for successful management, and also for correct interpretation of ecological investigations [7], so yellowfin sea bream, bottom-dwelling fish that bring them in intimate contact with sediment during parts or all of their life, is suitable candidate for toxicology testing.

\section{References}

1. Cossins AR, Crawford DL (2005) Fish as models for environmental genomics. Nature Rev Genet 6: 324-333.
2. Munawar M (2005) Ecotoxicological Testing of Marine and Freshwater Ecosystems. Taylor \& Francis Group, LLC: 293.

3. Hesp SA, Potter IC, Hall NG (2004) Reproduction biology and protandrous hermaphroditism in A. latus. Environ Biol Fish 70: 252-272.

4. Hedayati A, Hosseini AR (2012) Endocrine Disruptions Induced by artificial induction of Mercury on Seabream. Comparative Clinical Pathology.

5. Abol-Munafi AB, Umeda S (1994) The gonadal cycle of the yellowfin porgy, A. latus (Houttuyn) reared in the net cage at Tosa Bay, Japan. Suisanzoshoku 42: 135-144.

6. Fishbase 2010. www.fishbase.org

7. Hedayati AS, Savari A, Movahedinia A, Zare P, Bagheri T (2011) Serum Biochemical Change Induced by In vitro Sub Chronic Mercury Chloride in Yellowfin Sea Bream. Iranica Journal of Energy \& Environment 2: 208-214. 